\title{
STRATEGI KOMUNIKASI PEMASARAN DAYA TARIK WISATA ALAS KEDATON DI DESA KUKUH
}

\author{
I Gusti Ngurah Putu Dedy Wirawan ${ }^{\mathrm{a}, 1}$ \\ I Nyoman Yoga Segara \\ I Nyoman Alit Putrawan ${ }^{\mathrm{a}}$
}

\author{
a Universitas Hindu Negeri I Gusti Bagus Sugriwa Denpasar \\ ${ }^{1}$ Corresponding Author, email: dedywirawan76@yahoo.co.id (Wirawan)
}

\section{ARTICLE INFO}

\section{Article history:}

Received: 18-01-2021

Revised: 24-02-2021

Accepted: 12-03-2021

Published: 31-03-2021

Keywords:

Strategy. Marketing

Communication,

Alas Kedaton

Tourist Attraction

\section{ABSTRACT}

The management of Alas Kedaton tourism object is managed by the village so that the promotion has not been maximized, within five years the visitors of the archipelago have decreased while foreign visitors have experienced fluctuations, currently promotions only use brochures, as well as the lack of the government's role in marketing and infrastructure, issues that must be studied 1) what is the form of marketing communication for Alas Kedaton tourism object in Kukuh Village, Marga, Tabanan? 2) how can a marketing communication strategy be used to increase visitors? 3) what are the implications of integrated marketing communication (IMC) and the SOSTAC model. The results of the study found that the manager of Alas Kedaton tourism object must 1) Horizontal coordination between stakeholders is not optimal. Each stakeholder is still focused on his own business, (2) communication that focuses on the marketing mix has not been implemented, and (3) to establish good communication with the government regarding infrastructure development and promotion and to take advantage of village proximity. The heads of clans together with the government in an effort to help oversee information, submit proposals and promotions through online media. The implications of the Alas Kedaton tourism object marketing communication strategy in seeking communication effectiveness by considering the influence of communication include: 1) cognitive, namely eliminating ambiguity, forming attitudes and convincing the public about the products, media to be used in advertising planning. 2) affective to find feelings, attitudes, behaviors, and emotions in buying products offered by managers of Alas Kedaton tourism object. 3) behavior to determine intention or behavior in buying products offered at Alas Kedaton tourist attractions.

\section{PENDAHULUAN}

Daya Tarik Wisata Alas Kedaton merupakan wisata alam yang memiliki daya tarik wisata kera. Pada hakikatnya Daya Tarik Wisata Alas Kedaton menggunakan konsep Tri Hita Karana, bagaimana manusia menjaga hubungan secara harmonis dalam kehidupan. Ketiga hubungan tersebut meliputi hubungan keharmonisan dengan hubungan dengan Tuhan, sesama manusia, dan dengan alam sekitar, implementasinya, hubungan manusuai dengan tuhan dilihat dari upacara ritual yang dilaksanakan di pura, 
sedangkan kegiatan yang berhubungan dengan alam adalah penghormatan kepada tumbuhan yang di tunjukan dengan memberikan sesajen kepada tumbuhan yang ada di Daya Tarik Wisata Alas Kedaton disebut Tumpek Uduh, selain itu kegiatan ritual yang dilakukakan di daya tarik Wisata Alas Kedaton khusus yang berhubungan dengan hewan desebut Tumpek Kandang yaitu penghormatan kepada hewan, sehingga menjadi unggulan yang dapat menciptakan keharmonisan dan kedamaian kepada pengunjung. Selain itu Daya Tarik Wisata Alas Kedaton bisa digunakan sebagai tempat pelestarian tanaman langka, yajna (upacara), dan sebagai laboratorium alam bagi masahiswa, namun hingga saat ini pemanfaatanya belum maksimal. Seperti yang diberitakan pada Tribun Bali (https://bali.tribunnews.com diakses 13 Juni 2020), masyarakat Bali percaya bahwa kunci dari terjadinya kesejahteraan itu ada dua yaitu kesucian dan keseimbangan. Kedua hal ini tertuang dalam Wana Kertih yang merupakan bagian dari Sad Kertih yaitu enam konsep pelestarian lingkungan dalam ajaran Hindu. Wana Kertih merupakan upaya untuk melestarikan hutan. Dalam kitab Pancawati diajarkan tentang tiga fungsi hutan hingga dapat membangun hutan yang lestari yang disebut Wana Asri yang dibagi menjadi Maha Wana, Tapa Wana dan Sri Wana, ketiga konsep itu memiliki andil dalam perwujudan bahwa hutan merupakan paru-paru dunia Daya tarik Wisata Alas Kedaton dikelola langsung oleh desa setempat sehingga pendapatan dari Daya Tarik Wisata Alas Kedaton sangat berperan penting terhadap kesejahteraan masyarakat sekitar, dibuktikan dengan terciptanya lapangan pekerjaan pada Daya Tarik Wisata Alas Kedaton yang diperuntukkan bagi masyarakat di daerah tersebut

Berdasarkan kunjungan wisatawan ke Alas Kedaton mengalami penurunan, khususnya pada wisatawan Nusantara sedangkan kunjungan wisatawan asing mengalami fluktuasi, dengan menurunnya kunjungan akan memiliki dampak yang signifikan terhadap pendapatan masyarakat lokal, sehingga pemasaran yang dilakukan pada Daya Tarik Wisata Alas Kedaton belum maksimal, selain itu perlu digali potensi atraksi wisata budaya lokal dalam menunjang ketertarikan wisatawan untuk berkunjung, penelitian yang dilakukan oleh (Oka dan Sumawidari 2013:210) mengemukakan strategi pemasaran perlu dipertimbangkan dalam memasarkan Daya Tarik Wisata Alas Kedaton demi meningkatkan pertumbuhan ekonomi masyarakat lokal antara lain: memperkenalkan atau membentuk product brand identity bagi Daya Tarik Wisata Alas Kedaton, spirit of brand yang khas perlu ditonjolkan dalam pemasaran, yang lebih berorientasi ke segmen pasar lokal serta melakukan kerjasama pihak travel agent dalam memasarkan Daya Tarik Wisata Alas Kedaton ke depan.

Pokok permasalahan dalam penelitian ini adalah untuk melanjutkan dan melengkapi hasil rekomendasi penelitian sebelumnya tentang membuat strategi komunikasi pemasaran karena dianggap sebagai alat penting dalam meningkatkan kujungan dan pendapatan bagi Daya Tarik Wisata Alas Kedaton, pengelolaan Daya Tarik Wisata Alas Kedaton dikelola oleh desa, selain itu promosi yang dilakukan belum maksimal, dalam kurun waktu lima tahun pengunjung nusantara mengalami penurunan sedangkan pengunjung asing mengalami fluktuasi, berdasarkan hal tersebut penulis berniat untuk mencari strategi komunikasi pemasaran, dalam meningkatkan kunjungan wisatawan di Daya Tarik Wisata Alas Kedaton Kabupaten Tabanan, sehingga berdampak terhadap masyarakat local, sedangakan persepsi dari pengunjung terhadap pelayanan sudah dianggap baik.

\section{METODE PENELITIAN}

Jenis Penelitian yang digunakan dalam penelitian ini penelitian deskriptif dengan pendekatan yang bersifat kualitatif, penelitian ini memfokuskan pada komunikasi pemasaran 
Daya Tarik Wisata Alas Kedaton yang dilakukan oleh pihak pengelola. penelitian ini menggunakan instrument pokok yaitu penulis sendiri, sedangkan instrument penunjang ialah manajer pengelola Daya Tarik Wisata Alas Kedaton.

Dalam penelitian ini penulis menentukan sampel berdasarkan pertimbangan bahwa sampel yang dipilih memiliki informasiinformasi yang dimiliki dalam penelitian, dikarenakan informan merupakan manajer pengelola, serta mengetahui informasi tentang perkembangan dan sebagai orang yang memiliki kewenangan, kebijakan yang akan di ambil dalam melakukan pemasaran Daya Tarik Wisata Alas Kedaton. Sampel yang dipakai adalah Bapak I Wayan Semadi selaku manajer pengelola Daya tarik Wisata Alas Kedaton. Dalam penelititan ini penulis menggunakan tenik analisis data SOSTAC merupakan kepanjangan dari situation analysis, objectives, strategy, tactics, actions, dan control Chaffey \& Smith (2013:3)

\section{HASIL DAN PEMBAHASAN}

Komunikasi merupakan bagian dari manusia, sejak dari lahir sudah melakukan komunikasi. Komunikasi merupakan suatu proses seseorang, kelompok organisasi dan masyarakat menciptakan serta menggunakan informasi untuk terhubung dengan lingkungan, semakin hari semakin berkembang sosial media, kondisi metode komunikasi semakin digiring kearah penggunaan teknologi. Setiap informasi serta bentuk komunikasi melalui proses sehingga penyampaian pesan akan tesampaikan dengan maksimal, Liliweri dalam (Sutaryo, 2005:48) proses yang terjadi dalam komunikasi secara umum ada dua, secara primer (primary process) dan secara skunder (secondary process).

Berdasarkan hasil wawancara dan observasi lapangan selama penelitian peneliti menemukan bahwa Daya Tarik Wisata Alas Kedaton hanya melakukan proses komunikasi dengan cara melakukan kunjungan ke objek wisata dan travel agent dengan cara bertatap muka secara langsung serta menyampaikan maksud untuk melakukan penitipan brosur, serta memohon atau mengajak pemilik objek untuk membantu memasarkan Daya Tarik Wisata Alas Kedaton seperti pada gambar.

Gambar 1

Promosi ke objek Wisata

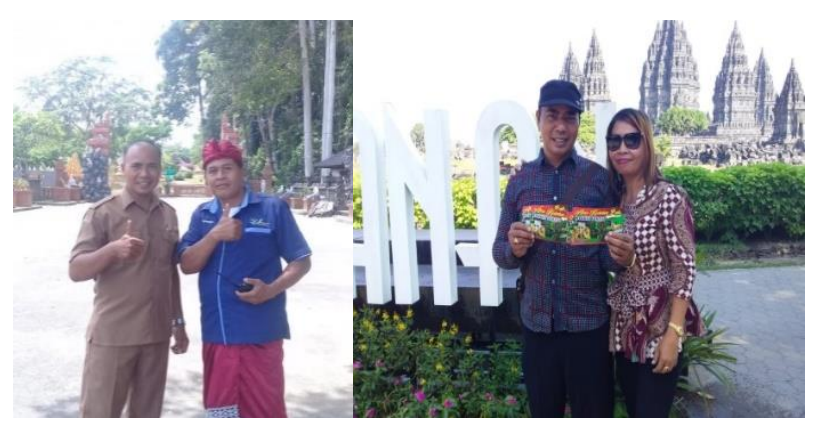

Sumber: dokumentasi Pengelola DTW Alas Kedaton (Mei, 2020)

Gambar di atas dapat dilihat bahwa bentuk kegiatan yang dilakukan oleh pihak pengelola menggunakan proses komunikasi secara primer yaitu tatap muka secara langsung antara pengelola dengan stakeholder atau orang lain untuk menyampaikan pikiran maupun perasaannya, tanpa alat, yaitu secara langsung, menggunakan bahasa gerakan yang diberi arti khusus, aba-aba dan sebagainya. Hal tersebut diperkuat dari hasil wawancara dengan pihak pengelola Daya Tarik Wisata Alas Kedaton.

"Komunikasi yang kami lakukan dalam mempromosikan Alas Kedaton adalah dengan melakukan kunjungan ke objek wisata serta menitipkan brosur pada objek tersebut, selain itu kami juga melakukan studi banding ke objek wisata lain yang ada di Bali maupun luar Bali, guna untuk mencari perbandigan dan inovasi apa yang dapat kami lakukan di DTW Alas Kedaton, selain itu kami juga bersinergi dengn Bendesa Adat yang sebagai penasehat dan memiliki kuasa penuh dalam menentukan anggaran, baik melakukan promosi serta pembuatan inovasi baru," (katua pengelola I Wayan Semadi, 25/5/2020)

Berdasarkan wawancara di atas pihak pengelola melakukan komunikasi langsung 
kepada stakeholder sudah terjadi proses komunikasi primer yang dkomunikator pihak pengelola bertatapan langsung dengan komunikan yaitu stakeholder, dengan dilakukan proses komunikasi ini secara langsung pihak pengelola mendapatkan respon secara langsung.

\section{Bentuk Komunikasi}

Berdasarkan hasil wawancara dan observasi dilapangan peneliti menemukan bahwa Daya Tarik Wisata Alas Kedaton selain menggunakan bentuk komunikasi interpersonal, kelompok massa dan komunikasi konvensional Daya Tarik Wisata Alas Kedaton juga melakukan komunikasi pemasaran terpadu. Hal ini juga ditemukan pada penelititan (Ariza, 2017) bahwa komunikasi pemasaran terpadu dengan menggunakan advertising, sales promotion, personal selling, direct marketing, interactive/internet marketing, direct marketing dan public relations merupakan bentuk komunikasi pemasaran untuk mencapai sasaran dan memastikan implementasinya secara tepat, sehingga tujuan serta sasaran utama organisasi akan tercapai. Komunikasi pemasaran terpadu yang dilakukan oleh Daya Tarik Wisata Alas Kedaton diantaranya:

Tabel 1 Komunikasi Pemasaran Terpadu Daya Tarik Wisata Alas Kedaton

\begin{tabular}{|c|c|c|c|c|c|}
\hline Advertisisng & Sales Promotion & $\begin{array}{l}\text { Personal } \\
\text { Selling }\end{array}$ & $\begin{array}{l}\text { Interactive/ } \\
\text { Internet } \\
\text { Marketing }\end{array}$ & Direct Marketing & Public Relation \\
\hline $\begin{array}{l}\text { Media Cetak: } \\
\text { - Brosur }\end{array}$ & Paket Wisata & $\begin{array}{l}\text { Interaksi } \\
\text { Dengan } \\
\text { Pengunjung }\end{array}$ & - & $\begin{array}{l}\text { Kerjasama } \\
\text { dengana pemilik } \\
\text { objek wisata lain }\end{array}$ & $\begin{array}{c}\text { Menjalin Kerjasama } \\
\text { Dengan Pihak Ketiga: } \\
\text { - } \quad \text { Travel Agaent }\end{array}$ \\
\hline $\begin{array}{l}\text { Media Luar } \\
\text { Ruangan: } \\
\quad \text { - Spanduk }\end{array}$ & $\begin{array}{l}\text { Informasi } \\
\text { Tentang } \\
\text { Keunggulan Alas } \\
\text { Kedatan }\end{array}$ & $\begin{array}{l}\text { Penyampaian } \\
\text { informasi ke } \\
\text { travel agent }\end{array}$ & - & Travel Agent & $\begin{array}{l}\text { Memeberikan } \\
\text { kesempatan kepada } \\
\text { masyarakat kukuh } \\
\text { untuk bekerja, serta } \\
\text { meningkatkan } \\
\text { pendapatan Desa Adat }\end{array}$ \\
\hline
\end{tabular}

$\begin{array}{lll}\text { Media Online } & \text { Atraksi Baru } & \text { Penyampaia } \\ \text { - Facebook Pribadi } & \text { Diskon } & n \text { informasi } \\ \text { Pengelola } & & \text { dari RRI } \\ \text { Radio } & & \end{array}$

Menyebar berita tentang Daya
Tarik Alas Kedaton

Sumber: Data Hasil Penelitian Daya Tarik Wisata Alas Kedaton

Berdasarkan hasil data yang diperoleh, dengan adanya strategi pemasaran terpadu yang tepat maka diperoleh hasil yang maksimal, dalam mencapai hasil yang maksimal pihak pengelola Daya Tarik Wisata Alas Kedaton harus menerapkan diantaranya: (1) untuk iklan (advertising), membuat website resmi Daya Tarik Alas Kedaton, bekerja sama dengan pihak ketiga baik dinas pariwisata maupun stakeholder lain untuk pengiklanan melalui spanduk, serta membuat akun media sosial. (2) untuk pemasaran langsung (direct marketing) pihak pengelola lebih banyak melakukaan pemasaran langsung ke pihak travel agent serta tour guide. (3) sedangkan untuk interactive/internet marketing perlunya merekrut SDM lokal yang memiliki keahlian dalam bidang IT, serta untuk mempromosikan Daya Tarik Wisata Alas Kedaton melalui internet. (4) untuk sales promotion sudah baik dalam memberikan diskon kepada travel agent, namun lebih baik apabila memberikan diskon kepada sekolah-sekolah dengan mengirimkan surat, maupun datang langsung kesekolah. (5) publikasi humas (public relation) perlu adanya seorang humas, karena dapat mengngkat atau citra positif Daya Tarik Wisata Alas Kedaton, selain itu dapat membangun hubungan kepada stakeholder dan. (6) personal selling perlu adanya pelatihan pelayanan sehingga menjadi satu palayanan yang baik serta pemberian informasi yang sama. 


\section{Analisis Menggunakan Model SOSTAC}

Untuk mengetahui strategi komunikasi pemasaran Daya Tarik Wisata Alas Kedaton yang telah dilakukan oleh pihak pengelola, maka akan dianalisis menggunakan analisis model SOSTAC, dan bauran pemasaran, diantanya: situation (situasi), objective (tujuan), strategy (strategi), tactics (taktik), action (aksi/implementasi), control (kontrol). Sedangkan pada unsur strateginya terdapat komponen-komponen penting yang perlu diperhatikan terdiri dari product, price, promotion, place atau yang disebut dengan bauran pemasaran (Morissan 2010:9).

\section{Situation (Situasi)}

Analisis pasar merupakan langkah awal dalam memasarkan Daya Tarik Wisata Alas Kedaton diantanya, untuk melihat bagaimana potensi dan kondisi dalam kaitannya mencari pangsa pasar pengunjung Daya Tarik Wisata Alas Kedaton menurut pengelola

"secara keseluruhan kunjungan kami memang menurun, namun peningkatan kunjungan pada wisatawan asing, pengunjung yang kami sasar adalah pengunjung yang suka alam serta dan binatang khususnya kera selaian itu kami juga melakukan studi banding ke objek wisata monkey forest dan sangeh, perbedaan yang kami liat adalah adanya dukungan pemerintah serta system pengelolaan yang berbeda sehingga kami tidak bias berkembang secara maksimal" (I Wayan Semadi 25/6/2020)

Hasil observasi yang dilakukan dan wawancara langsung dengan pihak pengelola serta pemangku kebijakan di Daya Tarik Wisata Alas Kedatan diperoleh hasil bahwa, Daya Tarik Wisata Alas Kedaton merupakan objek wisata yang di kelola desa, segala keputusan atau kegiatan yang dilakukan oleh pengelola harus melali parum atau rapat bersama desa adat dan kelian banjar Selain itu dalam mencari situasi menggunakan analisis kompetitior, SWOT, dan segmentasi pasar.

\section{Objective (tujuan)}

Tujuan pemasaran yang dimaksud sebagai berikut: (1) meningkatkan Pendapatan Desa; serta (2) meningkatkan kunjungan wisatawan. Sebagaimana yang disampaikan oleh Bendesa Adat bahwa

"Biaya operasional dan pemasaran sepenuhnya dikelola dari hasil pendapatan DTW, selain itu hasil pendapatan DTW digunakan untuk biaya odalan atau upacara ke agamaan yang ada di desa sehingga tidak membebani masyarakat, berdasarkan hal tersebut kami memiliki tujuan pemasaran. (I Gusti Ngurah Artha Wijaya 21/5/2020).

Berdasarkan dari hasil wawancara dengan narasumber di atas menjelaskan bahwa Daya Tarik Wisata Alas Kedaton selain untuk meningkatkan pendapatan dan kunjungan pihak pengelelola memiliki tujuan jangka panjang dan jangka pendek. Jangka panjang yang dimaksud adalah menjadi salah satu tujuan utama Daya Tarik Wisata Alas Kedaton dalam meningkatkan kesejahteraaan masyarakat Desa Adat Kukuh. sedangkan tujuan jangka pendeknya adalah meningkatkan kunjungan wisatawan, meningkatkan kepuasan pelanggan serta minat wisatawan untuk datang berkunjung kembali.

Tujuan komunikasi pemasaran wisata Daya Tarik Wisata Alas Kedaton adalah untuk positioning dan mem-branding, wisatawan yang berbasiskan budaya, hal tersebut diperkuat oleh Bendesa adat Desa Kukuh, Marga, mengatakan

" Pada awalnya Daya Tarik Wisata alas kedaton memiliki cerita unik dan sakral hal tersebut dapat dilihat dari setiap upacara keagamaan kami tidak menggunakan api serta waktu upacara tidak boleh sampai sandikala atau pukul 07.00 PM seta keunikan kera disini adalah Kera yang memiliki ekor panjang hal tersebut kami harapakan bisa menjadi identitas dari Daya Tarik Alas Kedaton. (21/5/2020 I Gusti Ngurah Artha Wijaya). 
Berdasarkan pengertian image suatu destinasi dapat diciptakan dari perasaan perorangan, kelompok atau pengetahuan, pengaruh eksternal seperti pengaruh dari para teman dan keluarga, iklan dan pengalaman masa lampau mereka (Beerli \& Martin, 2004). Dari hasil pengamatan pengelola Daya Tarik Wisata Alas Kedaton, dengan secara tidak langsung sudah melakukan place positioning dan branding hal ini sebagai cara menonjolkan wisata Daya Tarik Wisata Alas Kedaton.

\section{Strategy (Strategi)}

Dengan mempertimbangkan situasi, tujuan dan segmentasi yang diharapkan Daya Tarik Wisata Alas Kedaton maka strategi dan pemasaran yang dapat dilakukan adalah (1) Peningkatan pemahaman tentang pengelolaan sebuah Daya Tarik Wisata. Berdasarkan dalam panelitian (Rihati, Puspa dan Yasa 2019:9) pengembangan dan pemasaran daya tarik wisata merupakan faktor utama dalam meningkatkan tingkat kunjungan dan perekonomian daerah. Sehingga dalam mengelola Daya Tarik Wisata Alas Kedaton, perlu adanya persamaan persepsi antara pihak pengelola, penasehat serta seluruh staf dalam menjalankan visi dan misi. (2) Meningkatkan promosi dan publikasi melalui media online dengan moto, mengeluarkan dana sedikit namun berdampak besar kepada pngunjung. (3) Pengembangan SDM Daya Tarik Wisata Alas Kedaton dalam melakukan penyamaan persepsi perlu adanya Kegiatan pengembangan SDM diantanya mengikuti bimtek tentang pariwisata serta pelatihan terkait pemasaran dan cara pengelolan sebuah daya tarik wisata yang diadakan oleh dinas pariwiwsata Tabanan. (4) Meningkatkan koordinasi dan komunikasi kepada masayarakat sekitar atau penunjang Daya Tarik Wisata Alas Kedaton seperti pengrajin souvenir, guide lokal, Pemerintah Kabupaten Tabanan, Kepala Desa Adat Dinas serta kaum melinial yang ada di desa guna membantu memasarakan Daya Tarik Wisata Alas Kedaton. (5) Perbaikan infrastruktur dan fasilitas pendukung menjadi faktor penting dalam mengembangkan dan memasarkan Daya Tarik Wisata Alas Kedaton untuk kenyaman dan kemudahan akses bagi wisatawan yang berkunjung ke Daya Tarik Wisata Alas Kedaton. Seperti: pagar pembatas, kenyamanan sarana parkir, kebersihan, layanan informasi.

\section{Tactics (Taktik)}

Taktik pertama yang dilakukan pihak pengelola Daya Tarik Wisata Alas Kedaton adalah melakukan marketing research yaitu melakukan survey dan kajian pasar wisata. Analisa situasi sangat penting karena pengelola dapat mengetahui potensi Daya Tarik Wisata Alas Kedaton yang dimiliki serta dapat mengetahui keinginan dan harapan konsumen. Taktik kedua adalah meningkatkan promosi dan publikasi. Pihak Pengelola memanfaatkan sebanyak mungkin kegiatan dan inovasi yang dibuat di Daya Tarik Wisata Alas Kedaton dapat tersampaikan kepada konsumen atau calon konsumen. Taktik ketiga adalah membangun komunikasi, kerjasama dan berkoordinasi dengan stakeholder terkait, diantaranya kepala dinas Desa Kukuh, Bendesa Adat Kukuh, pemerintah Kabupaten Tabanan serta anak milenial yang ada di Desa Adat Kukuh, Menurut Mulyana, (2003:41) kata komunikasi atau communication dalam bahasa Inggris berasal dari kata Latin communis yang berarti "sama", communico, communication, atau communicare yang berarti "membuat sama" (to make common). Istilah pertama (communis) adalah istilah yang paling sering disebut sebagai asalusul kata komunikasi, yang merupakan akar dari kata-kata Latin lainnya yang mirip. Komunikasi menyarankan bahwa suatu pikiran, suatu makna, atau suatu pesan yang dianut secara sama.

\section{Action (aksi/implementasi)}


Aksi yang dijalankan pihak pengelola Daya Tarik Wisata Alas Kedaton beserta stakeholder sebagai berikut:

a. Marketing research merupakan bentuk dari upaya pihak pegelola Daya Tarik Wisata Alas Kedaton untuk mengetahui kebutuhan dan keinginan konsumen. Hal tersebut akan menjadi dasar dalam menentukan strategi pemasaran. Pihak pengelola Daya Tarik Wisata Alas Kedaton tidak dapat sendirian namun harus merangkul para stakeholder, diantaranya: a. Melakukan survey penyusunan data untuk menginventarisasi kekuatan produk seperti kebijakan yang didukung penuh oleh Kepala Desa, program dan pembiayaan, DTW yang banyak diminati oleh wisatawan mancanegara, serta memiliki keunikan dalam melaksankan upacara keagamaan. b. Melakukan survey kajian pasar adalah untuk mendapatkan gambaran tren pasar wisata saat ini, dan masa depan, serta pola dalam pengambilan keputusan. c. Melakukan survey terhadap pengunjung untuk mengetahui karakteristik pengunjung objek wisata sehingga dapat diperoleh informasi mengenai profil dan kebutuhan pengunjung kedepannya serta dapat dijadikan acuan untuk pengembangan objek/atraksi.

b. Meningkatkan publikasi dan promosi merupakan upaya menarik minat wisatawan untuk mengikuti kegiatan yang direncanakan seperti pihak pengelelola membuat atraksiatraksi wisata yang sesuai dengan budaya lokal diantaranya pemberian pakan kera pada jam tertentu, kegiatan ritual tumpek kandang serta kegiatan upacara piodan di pura yang ada pada kawasan Daya Tarik Wisata Alas Kedaton serta kegiatan lainnya. Harapanya dapat terekspos melalui media cetak maupun elektronik seperti koran, website dan internet sedangkan Kegiatan promosi yang dilakukan antara lain: 1) iklan (advertising), bekerja sama dengan pihak ketiga baik dinas pariwisata maupun stakeholder lain untuk pengiklanan melalui spanduk, serta membuat akun media sosial. (2) pemasaran langsung (direct marketing) pihak pengelola lebih banyak melakukaan pemasaran langsung ke pihak travel agent serta tour guide. (3) interactive/internet marketing perlunya merekrut SDM lokal yang memiliki keahlian dalam bidang IT, serta untuk mempromosikan Daya Tarik Wisata Alas Kedaton melalui internet. (4) sales promotion sudah baik dalam memberikan diskon kepada travel agent, namun lebih baik apabila memberikan diskon kepada sekolah-sekolah dengan mengirimkan surat, maupun datang langsung kesekolah. (5) publikasi humas (public relation) perlu adanya seorang humas, karena dapat mengngkat citra positif Daya Tarik Wisata Alas Kedaton, selain itu dapat menjalin hubungan kepada para stakeholder dan. (6) personal selling perlu adanya pelatihan pelayanan sehingga menjadi satu palayanan yang baik serta pemberian informasi yang sama.

c. Melakukan manajemen produk, harga dan tempat dalam rangka memasarkan Daya Tarik Wisata Daya Tarik Wisata Alas Kedaton tidak dapat bekerja sendiri, tetapi bekerjasama dengan stakeholder. Adakalanya kebijakan harga menjadi persaingan yang tidak sehat diantara stakeholder, berdasarkan pernyataan dari Bendesa Adat Kukuh

"Rencana kedepannya kami akan membuat paket-paket yang bisa bersaing dengan kompetitior atau objek wisata lain, saat ini kami melakukan kerjasama dengan kepada Kepala Desa terkait pengadaan wahana baru, sehingga bisa merencanakan sebuah paket atraksi yang dapat dilakukan di DTW Alas Kedaton, sasaran wahana yang kami sasar sementara adalah wisawan nusantara". (I Gusti Ngurah Artha Wijaya 15/06/2020)

d. Membangun komunikasi dan kerjasama kepada stakeholder, guna untuk mengetahui kelemahan dan kekurangan yang dimiliki Daya Tarik Wisata Alas Kedaton, sehingga 
dapat memaksimalkan pemasaran Tarik Wisata Alas Kedaton, yang perlu dilakukan pihak pengelola adalah: 1. Bekerjasama dengan dinas pariwisata Kabupaten Tabanan, 2. menjalin komunikasi, koordinasi dengan stakeholder terkait, kegiatan atraksi wisata yang dilakukan, ikut serta dalam asosiasi seperti PUTRI, ASITA. ikut serta dalam eventevent yang diadakan oleh kabupaten seperti pameran mengajak kaum milenial yang ada di desa untuk ikut serta dalam membangun Daya Tarik Wisata Alas Kedaton seperti menyusun kegiatan pada waktu acara tumpek kandang, upacara odalan di pura.

\section{Control / kendali atau pengukuran}

Berdasarkan hasil dari observasi lapangan dapat dilihat proses strategi komunikasi perlu dipantau dan dievaluasi secara menyeluruh, namun pemantauan dan evaluasi yang dilakukan di Daya Tarik Wisata Alas Kedaton hanya sebatas laporan keuangan dan laporan pengunjung hal tersebut diperkuat dari hasil wawancara dengan kepala desa Kukuh.

"Evaluasi yang kami lakukan hanya sebatas laporan rutin seperti pengunjung, dan laporan keuangan, sedang evaluasi program masih belum I Wayan Semadi 6/06/2020), berbeda halnya dengan Kepala Desa menyampaikan “ evaluasi kegiatan harus dilakukan dan disampaikan kepada penasehat pengelola guna mendapatkan data dan informasi terkait pendapatan dan keinginan dan kepuasan pengunjung sehingga kedepannya kita dapat menyusun strategi yang baik dan tepat sasaran. (I Made Sugianto 15/06/2020)

Seperti yang di sampaikan oleh kepala desa sesuai dengan pengertian evaluasi merupakan kegiatan yang terencana untuk mengetahui keadaan sesuatu objek dengan menggunakan instrumen dan hasilnya dibandingkan dengan tolak ukur untuk memperoleh kesimpulan" (Yunanda: 2009), jadi setiap kegiatan yang dilakukan di Daya Tarik Wisata harus di evaluasi setiap bulan maupun triwulan sekali, bertujuan untuk mengetahui rangkuman dari seluruh kegiatan yang dilakukan dalam memasarkan Daya Tarik Wisata Alas Kedaton, laporan-laporan yang perlu disusun berdasarkan strategi adalah (a) laporan respon pengunjung melalui media sosial dan internet. b) laporan survey tentang target pasar mengenai potensi Daya Tarik Wisata Alas Kedaton. c) Laporan kepuasan konsumen/klien (survey kepuasan tamu), selain itu laporan aktifitas promosi yang sudah terlaksana, seperti laporan survey lapangan.

\section{IMPLIKASI KOMUNIKASI PEMASARAN}

Berdasarkan dari hasil analisis tentang implikasi strategi komunikasi pemasaran Daya Tarik Wisata Alas Kedaton dalam mencari efektifitas komunikasi dengan mempertimbangkan efek komunikasi diantaranya: 1) Kognitif yaitu menghilangkan ambiguitas, membentuk sikap dan meyakinkan masyarakat terkait produk, media yang akan digunakan dalam perencanaan iklan. 2) Afektif untuk mencari perasaan, sikap, prilaku, dan emosional dalam membeli produk yang di tawarkan pengelola Daya Tarik Wisata Alas Kedaton 3) Behavioral untuk menentukan niat atau prilaku dalam membeli produk yang di tawarkan Daya Tarik Wisata Alas Kedaton.

1. Implikasi Terhadap Penguatan Kognitif

Berdasarkan dari hasil wawancara di atas upaya yang dilakukan untuk menguatkan efek kognitif dengan publikasi, dan membentuk media komunikasi sehingga seluruh kegiatan di Daya Tarik Wisata Alas Kedaton dapat terekspos melaui media cetak maupun elektronik. berdasarkan hasil kebijakan dalam menciptakkan produk Daya Tarik Wisata Alas Kedaton mengangkat tema budaya daerah sebagai atraksi wisata upacara keagaman menjadi ikon dari Daya Tarik Wisata Alas Kedaton. Perencanaan program tersebut merupakan strategi yang menggabungkan kebijakan Kepala Desa, Bendesa Adat serta 
pemerintah Kabupaten Tabanan dalam memasarkan Daya Tarik Wisata Alas Kedaton. dalam menciptakan sebuah icon dan brand tentunya langkah awal yang harus di ambil adalah membuat iklan di media cetak dan elektronik, sehingga minat wisatawan ingin berkunjung ke Daya Tarik Wisata Alas Kedaton.

\section{Implikasi Terhadap Pembentukan Afektif}

Aspek afektif adalah perasaan emosi, keinginan, maupun rasa suka dan rasa tidak suka yang dimiliki oleh konsumen. Komponen afektif menyangkut masalah emosional subjektif seseorang terhadap suatu objek sikap. Secara umum, komponen ini disamakan dengan perasaan yang dimiliki terhadap sesuatu. Pada umumnya, reaksi emosional merupakan komponen afektif banyak dipengaruhi oleh kepercayaan atau yang dipercayai sebagai benar dan berlaku bagi objek termaksud. Berdasarkan tujuan komunikasi pemasaran pada dasarnya adalah memberi efek afektif yaitu memberikan pengaruh kepada target sasaran untuk melakukan sesuatu (Priansa, 2014, h.96). Pemasaran memainkan peranan penting dalam pengembangan strategi, pertama bisnis apa yang digeluti perusahaan pada saat ini dan jenis bisnis apa yang dapat dimasuki di masa mendatang, kedua bagaimana bisnis yang dipilih tersebut dapat dijalankan dengan sukses dalam lingkungan yang kompetitif atas dasar perspektif produk, harga, promosi dan distribusi (bauran pemasaran) untuk melayani pasar sasaran. upaya yang dilakukan pihak pengelola dalam menumbuhkan keinginan konsumen dengan cara mengajak kaum milinial untuk berfoto di Daya Tarik Wisata Alas Kedaton serta mengajak seluruh jajaran Perbekel Desa Kukuh untuk melakukan kerja bakti, guna menumbuhakan kesadaran dan keinginan pungunjung dalam menjaga kelestarian hutan Daya Tarik Wisata Alas Kedaton hal tersebut diperkuat oleh Perbekel Desa Adat Kukuh,
"Jadi dengan kami mencuri-curi ilmu dan jurus di Objek Wisata lain, kunjungan kami Astungkara dalam satu Tahun terakhir lumayan meningkat terutama dari Wisatawan Asing" kegiatan yang kami lakukan dalam rangka gerakan revolusi mental aksi bersih serentak di Alas Kedaton (I Made Sugianto, 28/07/2020)

Selain itu upaya yang di lakukan dalam menunjang minat wisatawan untuk berkunjung ke Daya Tarik Wisata Alas Kedaton pihak pengelola selalu berkoordinasi dengan Bendesa Adat dalam pemberian anggaran untuk promosi, membuat inovasi baru, serta berkoordinasi dan kerjasama dengan pemerintah Kabupaten Tabanan membangun hubungan yang baik demi mencapai tujuan dan kepentingan bersama. Menjalin Komunikasi yang baik dengan pemerintah terkait pengembangan infrastruktur dan promosi serta memanfaatkan kedekatan kepala Desa Marga dengan pemerintah dalam upaya membantu mengawal informasi, pengajuan proposal dan promosi melalui media daring untuk terciptanya komunikasi yang efektif pada kunjungan wisatawan.

\section{Implikasi Terhadap Pengembangan Behaviour \\ Pengembangan Daya Tarik Wisata Alas} Kedaton sangat dirasakan manfaatnya dalam peningkatan perekonomian Desa Adat Kukuh Marga, oleh karena itu Daya Tarik Wisata Alas Kedaton sebagai modal dasar pengembangan pariwisata di Desa Kukuh, kegiatan atau proses yang berhubungan dengan bagaimana dan mengapa pelanggan memilih, membeli dan menggunakan suatu produk atau layanan yang ditawarkan Daya Tarik Wisata Alas Kedaton untuk memenuhi kebutuhan atau keinginan konsumen. Perilaku Konsumen sangat penting dalam manajemen pemasaran karena dapat membantu pemasar untuk memahami apa yang mendasari pelanggannya untuk memilih dan menggunakan produknya ataupun mengapa pelanggan memilih produk pesaing lain daripada produknya. Perilaku konsumen menurut Hasan 
(2013:161), perilaku konsumen adalah studi proses yang terlibat ketika individu atau kelompok memilih, membeli, menggunakan, atau mengatur produk, jasa, atau pengalaman untuk memuaskan kebutuhan dan keinginan konsumen. Hal yang dilakukan oleh pihak pengelola dalam pengembangan behavior konsumen adalah, menambah wahana ayunan putar serta pemberian pemanduan bagi pengunjung, serta artshop sepanjang pintu masuk gerbang Daya Tarik Alas Kedaton, sehingga pengunjung antusias berkunjung ke Daya Tarik Wisata Alas Kedaton

\section{SIMPULAN}

Berdasarkan pembahasan Strategi Komunikasi Pemasaran Daya Tarik Wisata Alas Kedaton Desa Kukuh Marga, Tabanan maka dapat disimpulkan bahwa: Bentuk komunikasi pemasaran yang digunakan Daya Tarik Wisata Alas Kedaton di Desa Kukuh komunikasi yang menitik berartkan kepada marketing mix sepenuhnya belum dijalankan seperti promosi menggunakan media sosial, dan internet. Strategi komunikasi pemasaran yang dilakukan Daya Tarik Wisata Alas Kedaton di Desa Kukuh Koordinasi horizontal dan vertikal antara stakeholder dan pemerintah belum maksimal dilakukan. berdasarkan hasil tersebut pihak pengelola sebaiknya menjalin komunikasi yang baik dan ikut serta dalam organisasi kepariwisataan karena informasi sangat penting untuk menentukan strategi yang tepat,

Daya Tarik Wisata Alas Kedaton, sebagai sumber daya alam yang memiliki keunikan hutan dengan kera ekor panjang serta kalong (kelelawar), penataan artshop, tradisi budaya masyarakat lokal, selain itu implikasi dalam mencari efektifitas komunikasi dengan mempertimbangkan efek komunikasi diantaranya: 1) implikasi penguatan kognitif membentuk media komunikasi sehingga semua kegiatan di Daya Tarik Wisata Alas Kedaton dapat terekspos melaui media cetak maupun elektronik, menciptakkan produk Daya Tarik
Wisata Alas Kedaton dengan mengangkat tema budaya daerah sebagai atraksi wisata upacara keagaman menjadi sebuah icon dan brand . 2) implikasi pembentukan afektif upaya yang dilakukan pihak pengelola dalam menumbuhkan keinginan konsumen dengan cara mengajak kaum milenial untuk berfoto di Daya Tarik Wisata Alas Kedaton serta mengajak seluruh jajaran Perbekel Desa Kukuh untuk melakukan kerja bakti, guna menumbuhakan kesadaran dan keinginan pungunjung dalam menjaga kelestarian hutan Daya Tarik Wisata Alas Kedaton. 3) implikasi pengembangan behavior yang dilakukan oleh pihak pengelola adalah, menambah wahana ayunan putar pemberian pemanduan bagi pengunjung, artshop sepanjang pintu masuk gerbang Daya Tarik Alas Kedaton serta mempertimbangkan tujuan orang berwisata ialah ingin menikmati atraksi, sekalipun harus menempuh jarak yang jauh serta dengan kondisi jalan yang buruk.

\section{SARAN}

Dari hasil penelitian yang sudah dilakukan penulis memberikan saran sebagai berikut: Penggunaan media online dimanfaatkan secara maksimal, karena sumber informasi yang paling banyak diperoleh oleh wisatawan saat ini adalah secara online, manfaatkan masyarkat lokal yang paham dibidang IT, untuk mempromosikan Daya Tarik Wisata Alas Kedaton. Berperan aktif dalam kegiatan pemerintah khususunya program dinas pariwisata Kabupaten Tabanan, yang terkait dengan penyelenggaraan event, aktif ikut serta dalam asosiasi, PUTRI, tour dan travel serta perkumpulan DTW yang ada di Kabupaten Tabanan, menjalin hubungan baik dengan stakeholder sehingga Daya Tarik Wisata Alas Kedaton menjadi lebih dikenal. Pihak pengelola, Bendesa dan Kepala Desa selalu bersinergi, untuk memajukan Daya Tarik Wisata alas Kedaton, sehingga dampak yang diterima berpengaruh terhadapat masyarakat, selain itu perlu dibuatnya pelatiha-pelatihan atau pertemuan rutin kepada staf Daya Tarik Wisata, 
walapun menganut sistem ngayah dan ditunjuk langsung, untuk terciptanya persamaan persepsi dan informasi terkait pelayanan di Daya Tarik Wisata Alas Kedaton, serta masukan untuk penelitian berikutnya agar dapat dilanjutkan secara penelitian kuantitatif dalam mengukur strategi yang sudah dibuat dan yang akan dijalankan sehingga dampak yang dihasilkan oleh strategi ini bermanfaat bagi pihak pengelola serta masyarakat Desa Kukuh.

\section{DAFTAR PUSTAKA}

Ariza, Muhammad Khoirul. 2017. Strategi Komunikasi Pemasaran Terpadu Objek Wisata Air Desa Ponggok Sebagai Desa Wisata Mandiri Di Klaten (Studi Deskriptif Kualitatif Penerapan Konsep Komunikasi Pemasaran Terpadu Objek Wisata Air Desa Ponggok Sebagai Desa Wisata Mandiri). Hasil Penelititan.

Beerli, A. \& Martin, J. (2004). Factors Influencing Destination Image, Annals of Tourism Research, 31 (3), 657-68.

Chaffey, Dave \& Smith, PR. 2013. E-Marketing: Exellence. UK: Butterworth-Heinemann.

Hasan, Ali. 2013. Marketing dan Kasus-Kasus Pilihan. Yogyakarta. CAPS (Center For Academic Publishing Service)

Morissan, 2010. Periklanan Komunikasi Pemasaran Terpadu. Jakarta. Kencana

Mulyana, Deddy. 2003.Ilmu Komunikasi : Suatu Pengantar.Bandung : PT. Remaja Rosda Karya

Priansa, Donni Juni. 2014.Perencanaan dan Pengembangan Sumber Daya Manusia.Bandung: Alfabeta

Rihati, Niluh Gede Hita, Ida Ayu Tary Puspa, I Ketut Wardana Yasa. 2019. Strategi IPemasaran Agrowisata Royal Cocoa sebagai Wisata Edukasi di Banjar Wongaya Beten Mengesta Kecamatan Penebel Kabupaten
Tabanan. Jurnal Pariwisata Budaya. Volume 4, Nomer 2.

Sutaryo,2005. Sosiologi Komunikasi. Yogyakarta: Arti Bumi Intaran

Yunanda, M. 2009. Evaluasi Pendidikan. Jakarta: Balai Pustaka.

https://bali.tribunnews.com/2017/12/15/tera pkan-konsep-wana-kertih-di-hutanmangrove-untuk-perubahan-iklim?page=2.

https://elib.unikom.ac.id/download.php?id=99 247/EfektivitasDanUkuran,

https://id.wikipedia.org/wiki/Kukuh, Marga, T abanan

https://ekonomi.kompas.com/read/2018/02/1 5/093533926/survei-nielsen-mediadigitaldan-media-konvensional-salingmelengkapi?page $=$ all 